\title{
Формирование дифракционных структур на пленках циркония с помощью лазерной записи и реактивного ионного травления
}

\author{
В.П. Корольков ${ }^{1}, \underline{\text { Р.И. Куи }}^{1,2, *}$, А.И. Малышев ${ }^{1}$, А.Е. Маточкин ${ }^{1}$, Д.А. Белоусов ${ }^{1}$ \\ ${ }^{I}$ Институт автоматики и электрометрии СО РАН \\ ${ }^{2}$ Новосибирский государственный университет \\ ${ }^{*}$ E-mail: r.i.kuts@mail.ru
}

DOI: 10.31868/RFL2020.170-171

С развитием субволновой дифракционной оптики возникает потребность в поиске методов повышения пространственного разрешения. С этой целью хорошо зарекомендовала себя технология прямой лазерной записи на тонких пленках переходных металлов.

При воздействии непрерывного или импульсного сфокусированного лазерного излучения на пленках циркония, нанесенных на подложку из плавленого кварца, был обнаружен эффект увеличения фазовой высоты структур относительно уровня пленки [1]. При толщине пленки $\sim 100$ нм диапазон изменения эффективной высоты структур, записанных с разной мощностью пучка, достигает 700 нм. С помощью атомно-силовой микроскопии было продемонстрировано наличие нанорешеток с периодом, равным шагу сканирования (200-400 нм) при диаметре записывающего пятна 450-700 нм. Данная субволновая решетка и создает эффект большой фазовой глубины. Обнаруженный эффект может быть применен для создания фазовых отражательных дифракционных оптических элементов (ДОЭ) с дифракционной эффективностью, превышающей $30 \%$.

Целью работы было исследование влияния реактивно-ионного травления (РИТ) на нанорешетки, сформированные лазерной записью на тонкой пленке циркония. Тонкая пленка циркония толщиной 104 нм была нанесена на кварцевую подложку методом магнетронного напыления. Прямая лазерная запись производилась на установке XY лазерного нанолитографа с длиной волны записывающего лазера 405 нм. Были записаны тестовые структуры, шириной 5 мкм с различной мощностью записывающего излучения в диапазоне 9-14 мВт. Шаг по поперечной координате при записи был равен 250 нм. Соответственно, период продольных наноструктур равен шагу записи. С помощью интерферометрии белого света были получены зависимости эффективной фазовой глубины от мощности излучения.

Далее образец с записанными структурами был подвергнут реактивноионному травлению. В качестве активного реагента был выбран газ $\mathrm{CF}_{4}$, который входил в состав газовой смеси вместе с кислородом в пропорции 14:1. Через каждые 20 минут травления фиксировались оптические свойства структур. Показано, что при определенном времени травления эффективная высота относительно уровня пленки металла может быть существенно увеличена на участках, где не был достигнут максимум при лазерной записи. Возможность изменения эффективной высоты рельефа с помощью РИТ позволяет производить подстройку интегральной дифракционной эффективности ДОЭ после лазерной записи.

Данная работа выполнена в рамках реализации гранта РНФ №17-19-01721-П. 


\section{Литература}

[1] V. P. Korolkov, S.L. Mikerin, и др, Презентация на Международной конференции ALT-2019, Прага, 15-20 сентября 2019. 